\title{
A clinical evaluation of Placental Growth Factor in routine practice in high-risk women presenting with suspected pre-eclampsia and/or fetal growth restriction
} DOI:

10.1016/j.preghy.2018.03.007

\section{Document Version \\ Accepted author manuscript}

Link to publication record in Manchester Research Explorer

Citation for published version (APA):

Ormesher, L., Johnstone, E., Shawkat, E., Dempsey, A., Chmiel, C., Ingram, E., Higgins, L., \& Myers, J. (2018). A clinical evaluation of Placental Growth Factor in routine practice in high-risk women presenting with suspected preeclampsia and/or fetal growth restriction. Pregnancy Hypertension, 14, 234-239.

https://doi.org/10.1016/j.preghy.2018.03.007

\section{Published in:}

Pregnancy Hypertension

\section{Citing this paper}

Please note that where the full-text provided on Manchester Research Explorer is the Author Accepted Manuscript or Proof version this may differ from the final Published version. If citing, it is advised that you check and use the publisher's definitive version.

\section{General rights}

Copyright and moral rights for the publications made accessible in the Research Explorer are retained by the authors and/or other copyright owners and it is a condition of accessing publications that users recognise and abide by the legal requirements associated with these rights.

\section{Takedown policy}

If you believe that this document breaches copyright please refer to the University of Manchester's Takedown Procedures [http://man.ac.uk/04Y6Bo] or contact uml.scholarlycommunications@manchester.ac.uk providing relevant details, so we can investigate your claim.

\section{OPEN ACCESS}




\section{Accepted Manuscript}

A clinical evaluation of Placental Growth Factor in routine practice in high-risk women presenting with suspected pre-eclampsia and/or fetal growth restriction

L. Ormesher, E.D. Johnstone, E. Shawkat, A. Dempsey, C. Chmiel, E. Ingram, L.E. Higgins, J.E. Myers

PII:

S2210-7789(18)30023-0

DOI: https://doi.org/10.1016/j.preghy.2018.03.007

Reference: PREGHY 408

To appear in:

Pregnancy Hypertension: An International Journal of Women's Cardiovascular Health

Received Date: $\quad 23$ January 2018

Revised Date: $\quad 9$ March 2018

Accepted Date: $\quad 12$ March 2018

Please cite this article as: Ormesher, L., Johnstone, E.D., Shawkat, E., Dempsey, A., Chmiel, C., Ingram, E., Higgins, L.E., Myers, J.E., A clinical evaluation of Placental Growth Factor in routine practice in high-risk women presenting with suspected pre-eclampsia and/or fetal growth restriction, Pregnancy Hypertension: An International Journal of Women's Cardiovascular Health (2018), doi: https://doi.org/10.1016/j.preghy.2018.03.007

This is a PDF file of an unedited manuscript that has been accepted for publication. As a service to our customers we are providing this early version of the manuscript. The manuscript will undergo copyediting, typesetting, and review of the resulting proof before it is published in its final form. Please note that during the production process errors may be discovered which could affect the content, and all legal disclaimers that apply to the journal pertain. 


\section{A clinical evaluation of Placental Growth Factor in routine practice in high-risk women} presenting with suspected pre-eclampsia and/or fetal growth restriction.

\section{Authors}

Ormesher $L^{1,2}$, Johnstone $E D^{1,2}$, Shawkat $E^{1,2}$, Dempsey $A^{1,2}$, Chmiel $C^{2}$, Ingram $E^{1,2}$, Higgins, $L E^{1,2}$, Myers JE $\mathrm{J}^{1,2}$

1. Maternal \& Fetal Health Research Centre, Division of Developmental Biology and Medicine, School of Medical Sciences, Faculty of Biology, Medicine and Health, University of Manchester, Manchester Academic Health Science Centre, Manchester M13 9PL.

2. St Mary's Hospital, Central Manchester University Hospitals NHS Foundation Trust, Oxford Road, Manchester M13 9WL.

\section{Corresponding author}

Jenny Myers

Maternal \& Fetal Health Research Centre, The University of Manchester, St Mary's Hospital, Oxford Road, Manchester. M13 9WL

Jenny.myers@manchester.ac.uk 01617016963

\section{Abstract}

Objective: To evaluate the use of plasma Placental Growth Factor (PIGF), recommended by the recent NICE guidance, in women with suspected pre-eclampsia (PE) and/or fetal growth restriction (FGR).

Study design: Non-randomised prospective clinical evaluation study in high-risk antenatal clinics in a tertiary maternity unit.

Methods: PIGF testing was performed in addition to routine clinical assessment in 260 women $>20$ weeks' gestation with chronic disease (hypertension, renal disease \pm diabetes) with a change in maternal condition or in women with suspected FGR to determine the impact on clinical management. Results were revealed and standardised care pathways followed.

Main outcome measures: Outcome of pregnancies with a low PIGF (<12pg/ml and 13-100pg/ml), impact on clinical service and the diagnostic accuracy of alternative PIGF cut-offs. 
Results: 206/260 (79.2\%) women had an adverse outcome (PE/birthweight $<10^{\text {th }}$ centile/preterm birth). In our cohort, a low PIGF ( $<12 \mathrm{pg} / \mathrm{ml})$ was associated with a shorter test-birth interval and universally (100\% PPV) with an adverse pregnancy outcome, although 29/61 (47.5\%) of women with $\mathrm{PIGF}<12 \mathrm{pg} / \mathrm{ml}$ continued their pregnancy $>14$ days. The PIGF result altered clinical management (surveillance or timing of birth) in 196/260 (75.4\%) cases. Alternative PIGF thresholds did not significantly improve diagnostic performance.

Conclusions: Our evaluation confirms the value of PIGF as a diagnostic tool for placental dysfunction. However, low PIGF in isolation should not trigger iatrogenic delivery. Further research linking placental pathology, maternal disease and maternal PIGF levels is urgently needed before this test can be implemented in routine clinical practice.

Kevwords: placental growth factor, pre-eclampsia, fetal growth restriction, small for gestational age, preterm delivery, high-risk pregnancy. 


\section{Introduction}

Pre-eclampsia (PE) and fetal growth restriction (FGR) are common conditions associated with significant maternal and perinatal morbidity and mortality $(1,2)$. Much of the morbidity is attributable to high rates of obstetric intervention and iatrogenic preterm delivery, indicated because of the risk of severe maternal complications and stillbirth(3). It is recognised that PE and FGR are poorly defined manifestations of placental dysfunction, where current diagnostic criteria rely on imprecise clinical signs and/or arbitrary laboratory test cut-offs. PE is classically defined as new onset hypertension (systolic $\geq 140$ or diastolic $\geq 90 \mathrm{mmHg}$ ) occurring after 20 weeks' gestation with new proteinuria (protein:creatinine ratio $\geq 30 \mathrm{mg} / \mathrm{mmol}$ ) (4). However, there are many atypical presentations of PE, which do not fit these diagnostic thresholds (5). For example, women with preexisting renal disease and hypertension frequently have pre-pregnancy proteinuria, but are also at increased risk of developing PE (6). As a result the diagnosis of PE in this group of high-risk women is challenging and potentially contributes to the misclassification of pregnancies at highest risk of severe complications and unnecessary premature deliveries.

Recently an imbalance between pro-(placental growth factor (PIGF)) and anti-angiogenic (soluble fms-like tyrosine kinase-1 (sFlt)) factors has been implicated in the pathogenesis of PE. Preclinical(7), in vitro(8) and ex vivo studies(9) have all demonstrated a reduction in PIGF and/or an elevation of sFlt in the context of PE and placental dysfunction. Previous clinical studies have also demonstrated that there is a significant change in circulating angiogenic markers in women who develop PE and those with related placental dysfunction(10-13). The NICE Diagnostics Assessment Panel(14) recently reviewed the published literature related to the clinical utility of angiogenic marker testing in suspected PE and concluded that a negative test could be used to safely rule out disease for the next 7-14 days (REF). However, uncertainty about the interpretation of a positive test meant that NICE did not recommend its use to rule in disease. In view of this evidence gap we performed a clinical evaluation of PIGF testing in high-risk pregnant women with suspected PE and/or FGR, i.e. women with developing placental dysfunction. The primary aim of the study was to 
describe the outcome of pregnancies managed in the context of a low $(<12 \mathrm{pg} / \mathrm{ml})$ or intermediate (13-100pg/ml) PIGF measurement. The secondary outcomes were to evaluate the impact on clinical practice in a tertiary UK maternity unit and to determine whether a gestation-corrected PIGF centile would provide improved diagnostic accuracy in women with an intermediate PIGF result.

\section{Methods}

PIGF (Alere Triage ${ }^{\mathrm{TM}}$ ) testing was performed in addition to routine clinical assessment in 260 women attending the Manchester Antenatal Vascular Service Clinic (MAViS) or the Manchester Placenta Clinic (MPC) high-risk antenatal clinics between December 2013 to November 2015 at St Mary's Hospital, Manchester. The test was performed when there was a change in maternal condition noted after 20 and <37 weeks' gestation in women with pre-existing maternal disease and/or an ultrasound scan identified concerns regarding placental function (oligohydramnios, reduced abdominal circumference $(\mathrm{AC})$ growth velocity, estimated fetal weight $(\mathrm{EFW})<10^{\text {th }}$ centile, absent umbilical artery Doppler end-diastolic-flow). Women included in the clinical evaluation were all high risk with a history of either maternal disease (e.g. hypertension, renal disease, diabetes), previous early-onset PE, and/or risk factors for the development of FGR (e.g. euploid pregnancies with abnormal maternal serum biomarkers or previous FGR). The PIGF test result was available to the clinician within twenty-four hours of testing and used as an adjunct to standard clinical assessment. PIGF was classified as either normal $(>100 \mathrm{pg} / \mathrm{ml})$, intermediate $(13-100 \mathrm{pg} / \mathrm{ml})$ or low $(<12 \mathrm{pg} / \mathrm{ml})$ and a care pathway was developed incorporating standard clinical management guidelines $(15,16)$ with inclusion of the PIGF result (supplementary figure 1). PIGF was repeated if the initial result was normal or intermediate in women where there continued to be a clinical suspicion of PE or concerns regarding fetal wellbeing.

After 24 weeks, all routine growth scans included fetal biometry, amniotic fluid index (AFI) and umbilical artery Doppler (UAD). In the absence of an indication to repeat the scan earlier (e.g. estimated fetal weight $<10^{\text {th }}$ centile, reduction in growth velocity, $A F I<5^{\text {th }}$ centile, UAD $>95^{\text {th }}$ centile or absent end-diastolic-flow) ultrasound scans were repeated at 2-4 week intervals dependent on 
the gestation, severity of maternal disease or other clinical concerns (e.g. maternal anxiety or presentation with reduced fetal movements). In women where an abnormality was identified, additional fetal Dopplers were performed in line with standard SGA guidelines (16).

Clinical data were entered real time using a standard electronic patient record (Viewpoint) with information related to ongoing management, clinical diagnosis and delivery planning collected prospectively at each consultation. PE was defined as new hypertension or a deterioration in blood pressure (requiring instigation of treatment or an increase in medication) after 20 weeks' gestation with new proteinuria (protein:creatinine ratio $>30 \mathrm{mg} / \mathrm{mmol}$ ) in those without previous proteinuria or the development of haematological or biochemical abnormalities indicative of $\operatorname{PE}(4,17)$. Small for gestational age (SGA) was defined as a customised birthweight (BW) centile less than the $10^{\text {th }}$ centile(18). Pregnancy outcomes were captured from the electronic patient record (CMIS and K2) after birth. The clinical diagnosis and an assessment of a change in clinical management (frequency of maternal / fetal surveillance; inpatient admission; and timing of delivery) influenced by the PIGF result was assessed from the contemporaneous electronic patient record by two independent reviewers.

Data analysis

Data were exported from electronic patient records and missing information retrieved from case notes where necessary. In cases where repeat PIGF testing was performed, the test nearest birth was analysed. Clinical characteristics and the test-birth interval (days) were compared between groups according to the PIGF test result, the indication for the test and the final clinical diagnosis. PIGF centiles were calculated using Saffer et al.'s data from 1366 samples from 247 healthy pregnant controls (19). Continuous data were compared between groups using Wilcoxon rank sum test. Cox regression was used to investigate the effect of different PIGF categorisation methods on pregnancy outcomes. Statistical significance was set at 0.05 and all analyses were performed using Stata version 14.1. 


\section{Results}

260 women with suspected placental dysfunction (PE and/or FGR) were included in this study. The clinical characteristics of the cohort are presented in table 1 . The cohort represents a multi-ethnic population with $45.8 \%$ classified as White British ethnicity. 78 (30.0\%) of the cohort tested were subsequently judged to have a clinical diagnosis of PE, of whom 32 (41.0\%) delivered $<34$ weeks' gestation. $111(42.7 \%)$ had a pregnancy complicated by SGA without features of maternal disease (22 (19.8\%) delivered <34 weeks' gestation). There were three intra-uterine deaths (all BW $<3$ rd centile; 26-37 weeks' gestation; 333-2190g). One of these deaths was anticipated in view of the severity of FGR (birthweight 333g) and preterm gestation (26 weeks). The two remaining deaths were not anticipated. One occurred in a pregnancy complicated by SGA identified at 26 weeks' (normal umbilical artery Doppler and continued growth) and monitored until 33+6 weeks' gestation; delivery had been arranged for 34 weeks. The third death occurred unexpectedly at $36+4$ weeks in a pregnancy in which SGA had been identified at 33+6 weeks' gestation (normal liquor volume, umbilical and uterine artery Dopplers) and is discussed below.

\section{Outcomes of pregnancies according to PIGF result}

As expected, a significantly higher proportion of women $(38 / 61 ; 62 \%)$ with low $(<12 \mathrm{pg} / \mathrm{ml})$ PIGF delivered before 34 weeks' gestation, compared with those with a normal PIGF (9/124; 7.3\%; $\mathrm{p}<0.0001$ ). All of the women with a low PIGF had an abnormal pregnancy outcome (preterm birth and/or clinical diagnosis of PE or SGA at birth); in the group with an intermediate PIGF, 67/85 (89.3\%) had an abnormal pregnancy outcome with 11 (14.7\%) requiring delivery before 34 weeks. Supplementary Figure 2 shows a Kaplan Meier graph of the gestation at birth, for women with a PIGF categorised as low / intermediate / normal, demonstrating significantly earlier deliveries in the intermediate and low PIGF groups $(p<0.0001)$

Figure 1 summarises the test-birth interval according to the PIGF result nearest delivery. In contrast to previous reports, 29/61 (48\%) of women with a low PIGF continued their pregnancy for more than 14 days after the test was performed, using our care pathways. In the majority of these cases 
$(22 / 29,75.9 \%)$ this was because the pregnancy was of a gestation where conservative management was considered to be beneficial. 18/29 (62.1\%) of these women had PE and 9/29 (31.0\%) had SGA without features of maternal disease. Figure 1 also demonstrates "false negative" results. Test-birth interval, depending on PIGF indication and pregnancy outcome, is shown in supplementary table 1. False negative results

In eleven pregnancies the PIGF was $>100 \mathrm{pg} / \mathrm{ml}$ but preterm delivery within 14 days of testing was still offered (supplementary table 2 Figure 1). In the majority of these cases early delivery was not indicated by placental dysfunction: spontaneous $(n=1)$, indicated by other maternal disease $(n=3)$ or previous history of stillbirth $(n=2)$. In the remaining five pregnancies a decision for early delivery was indicated by acute fetal compromise ( $n=2$; antepartum haemorrhage and abnormal CTG), nonreassuring ultrasound fetal assessment ( $n=2$; reduced growth velocity/oligohydramnios) and a clinical diagnosis of PE in a woman with antiphospholipid antibody syndrome $(n=1)$. There were no false negative tests within 7 days of clinical diagnosis of $P E$, but 11 women subsequently developed PE (median 31[7-78 days]). Likewise, 56/124 (45\%) women with a normal PIGF had a final clinical diagnosis of SGA; three within 7 days of testing. There were two important false negative results in women with SGA. One pregnancy was complicated by undiagnosed preterm FGR (BW centile 1.6) requiring delivery at 32 weeks (indicated by an abnormal CTG) with a PIGF result of $159 \mathrm{pg} / \mathrm{ml}\left(10.4^{\text {th }}\right.$ gestation-adjusted centile) five days before birth. The other pregnancy was complicated by a stillbirth at 37 weeks, which occurred in a growth restricted baby (BW centile 1.4) 23 days after a test result of $531 \mathrm{pg} / \mathrm{ml}$ (the test was not repeated as subsequent ultrasound surveillance was reported as normal). The diagnostic accuracy against a clinical diagnosis of PE and/or SGA is summarised in supplementary table 3 .

\section{Effect on clinical management}

Figure 2 summarises the impact of the PIGF result on clinical management. In 79/124 (63.7\%) cases the scan surveillance interval was lengthened following a normal PIGF result, usually resulting in an 
interval of 2-3 weeks between scans rather than a week. There was less impact on maternal surveillance, however $31 / 124(25.0 \%)$ of women had reduced maternal surveillance secondary to a normal PIGF result and 21 maternal admissions were deemed to have been avoided in women with pre-existing maternal disease who had suspected signs of PE. Timing of birth was judged to have been adjusted according to the PIGF result in 113/260 (43.5\%) cases. 24 preterm ( $<37$ weeks) deliveries were delayed until >37 weeks following a normal or intermediate result (median gestational age at birth $37+4[37+0-41+1]) ; 52$ deliveries were expedited following a low or intermediate PIGF result resulting in an estimated 42 additional preterm ( $<37$ weeks) deliveries (median gestation at delivery $35+0[27+1-36+6]$ ).

\section{Application of alternative cut-offs for PIGF measurement}

The clinical utility of an intermediate PIGF result is uncertain(5) and in the current cohort was a poor discriminator for placental dysfunction (specificity $52.9 \%$ within 14 days of testing $(n=93)$ ). A posthoc exploratory analysis was therefore carried out by categorising PIGF using a gestation adjusted centile with $\mathrm{a}<5^{\text {th }}$ or $<3^{\text {rd }}$ centile cut-off or a lower threshold of $50 \mathrm{pg} / \mathrm{ml}$ to define an abnormal test using the outcomes preterm delivery ( $<37$ weeks) and complicated pregnancy (delivery $<37$ weeks or $>37$ weeks with SGA +/-PE). Whilst there was a significant increase in the specificity of the centile cut-off, this was at the expense of the sensitivity (table 2). In this cohort, where the test was revealed to the clinician, the test performance was comparable using the different thresholds, with slight improvement using a $<3^{\text {rd }}$ centile cut-off.

The relationship between different PIGF categorisation methods and gestation at delivery were compared using cox regression. The standard cut-off at 100pg/ml (HR 1.67 [1.18-2.37]; $p=0.004)$ was associated with an equivalent hazard ratio to a $3^{\text {rd }}$ centile cut-off (HR 2.33 [1.07-5.04]; $p=0.033$ ) but higher than a $5^{\text {th }}$ centile cut-off (HR 1.14 [0.53-2.48]; $\left.p=0.734\right)$. In women with a PIGF measurement before 34 weeks ( $n=157), 49 / 75(65 \%)$ with a result $<5^{\text {th }}$ centile delivered before 34 weeks (compared to $49 / 72$ (68\%) with a PIGF $<100 \mathrm{pg} / \mathrm{ml}$ ); the NPV was comparable at $89 \%$. In women with a PIGF<50pg/ml ( $\mathrm{n}=62), 48$ (77\%) delivered $<34$ weeks; the comparative NPV was 85/95 (89\%). Over 
the whole cohort $109 / 114(95.6 \%)$ of women with a PIGF $<5^{\text {th }}$ centile had complicated clinical outcomes, compared to $126 / 136$ (92.6\%) with a PIGF <100pg/ml and 105/109 (96.3\%) using a cut-off of $50 \mathrm{pg} / \mathrm{ml}$. 


\section{Discussion}

\section{Main findings:}

This study describes the clinical evaluation of a new diagnostic test for suspected PE and FGR which has recently been recommended by NICE(14) but has not been widely adopted in the UK to date. In line with previous reports we observed that a low PIGF result $(<12 \mathrm{pg} / \mathrm{ml})$ was universally associated with an adverse pregnancy outcome. However, in contrast to previous reports, in nearly half of the women in this cohort who had a low PIGF ( $n=61)$ the pregnancy continued for more than 14 days. This most likely reflects the fact that this study included a cohort enriched with a disproportionately high number of women with severe early-onset placental dysfunction in comparison to previous studies $(11,12)$, at a gestation where expectant management was desirable.

An assessment of the impact on clinical practice was captured prospectively in this study, although this is not a substitute for a randomized study, it does reflect the impact the result had on management within a tertiary centre. It is likely that maternal admissions were reduced and a significant number of ultrasound scans were safely avoided as a result of the use of a PIGF test. However, it is important to note that scan surveillance was not reduced in all women with a normal PIGF result, demonstrating that other factors (e.g. maternal condition, obstetrician preference) will continue to influence the number of scans offered to women; this observation needs to be considered in health economic assessments in the future. Whereas the decision to offer birth was delayed in 24 pregnancies to more than 37 weeks following a normal PIGF test, we estimated that up to 42 iatrogenic preterm births were influenced by the PIGF test result. Whilst it is plausible to hypothesise that this intervention prevented some severe adverse outcomes, it highlights the potential significant increase in neonatal morbidity, which may be associated with the introduction of angiogenic marker testing in routine clinical practice. In this study we set out to estimate the impact of the perceived increase in diagnostic certainty provided by the PIGF test on obstetric decision making, but in the absence of evidence to support the prognostic value of the test or its use to 'rule-in' disease(14), local guidelines for iatrogenic birth did not include the PIGF result. There was 
one stillbirth (33+6 weeks) in a pregnancy complicated by a very low PIGF $(n=61)$. Despite intensive surveillance a recognised indication for birth was not identified before the planned birth at 34 weeks.

The prevalence of pre-gestational medical disease (hypertension, renal disease, diabetes) in this cohort was much higher than the general obstetric population. This provided an important opportunity to evaluate the test in a high-risk cohort, where the diagnosis of PE by current criteria is often difficult. This study has demonstrated that PIGF was particularly useful in this group and directed a more efficient use of resources (intensive antenatal surveillance, hospital admissions and iatrogenic early delivery) without compromising maternal-fetal safety. The lack of an accepted gold standard definition of PE in women with pre-existing hypertension and renal disease, may in the future be supplanted by the incorporation of maternal serum PIGF to discriminate between deteriorating medical disease and PE.

Centile cut-offs did not offer much improvement over the traditional intermediate cut-off of 100pg/ml: specificity was improved whilst sensitivity was significantly reduced. This conclusion is consistent with prior conclusions of Chappell et al(5).

\section{Strength and limitations}

Our study was neither randomised nor blinded to the managing clinicians, and thus our findings are potentially subject to treatment paradox. We attempted to control for this by conducting the study in a specialist unit, deploying resources to maximise gestational age at delivery. Despite these limitations we feel the study has important implications for adoption of this test in high-risk women with suspected placental dysfunction. Despite the absence of a comparison group, this prospective clinical evaluation study was designed with contemporaneous data collection and therefore aimed to capture and describe the impact of the test on clinician practice in the management of suspected placental dysfunction. Furthermore, in this study it was only possible to compare PIGF measurements to clinical diagnoses, which are frequently incorrect. A much more robust comparison would include placental histological assessment, thereby increasing the certainty of 
underlying placental dysfunction. An additional limitation is that this study was carried out in a tertiary referral centre within a high-risk cohort and a disproportionately high rate of preterm placental disease, which may limit applicability to general obstetric populations. A step-wedge randomised study (PARROT ISRCTN16842031) is currently underway at several hospitals in the UK (including St Mary's, Manchester) and will evaluate the time to diagnosis of PE before and after implementation of PIGF testing in women presenting with suspected PE. The PARROT study will also provide important supplementary cost utility information that can be added to the NICE Diagnostic Assessment Panel (14) cost evaluation; this was not possible in the current study due to the lack of a comparator group. Finally, we assume that the link between iatrogenic preterm birth and low maternal PIGF is underlying placental dysfunction resulting in an abnormal angiogenic secretory pattern from placental villi $(20,21)$. Future studies in high-risk women would benefit from the inclusion of placental pathology(22).

\section{$\underline{\text { Interpretation }}$}

The selective use of PIGF testing influenced the clinical management of women with suspected placental dysfunction potentially both reducing and increasing intervention where required. Although inevitably decisions on intervention were influenced by the PIGF result, women were not delivered on a PIGF result alone. This is demonstrated by the high number of pregnancies that continued $>14$ days when PIGF was $<12 \mathrm{pg} / \mathrm{ml}$ without adverse outcome and highlights the need for the PIGF result to be taken in context with other validated prognostic markers such as umbilical artery Doppler measurement.

In the UK, the NICE diagnostic assessment panel(14) recently recommended angiogenic marker testing to exclude PE within one week. This was based on data from studies using PIGF and the sFIt:PIGF ratio $(5,11)$. Our results support this recommendation for placental dysfunction with a maternal component, as we had no diagnoses of PE within 7 days of a normal PIGF result. In this high-risk cohort angiogenic marker testing also assisted in the management of suspected SGA with a detection rate of $80 \%$ within a week, however two cases of severe FGR were not identified by an 
abnormal PIGF result (test-birth interval 5 days) highlighting the heterogeneous aetiology of this condition and the ongoing need for further research regarding the relationship between placental dysfunction and maternal angiogenic marker levels(13).

To conclude, our evaluation confirms the value of PIGF as a highly valuable diagnostic tool for placental dysfunction, particularly in the presence of maternal disease, which is likely to influence obstetric management and timing of birth. However, it has highlighted that several evidence gaps remain which should caution the introduction of this test into routine clinical practice, particularly in normotensive SGA. It also confirms that abnormal PIGF levels in isolation are not an indication for delivery. Further research linking placental pathology, maternal disease and maternal PIGF levels is therefore urgently needed to further inform the clinical utility of angiogenic marker tests.

\section{Acknowledgements}

Not applicable.

\section{Disclosure of interests}

I certify that none of the authors have any relevant financial and/or non-financial relationships to disclose.

\section{Contribution to authorship}

I certify that each co-author listed participated sufficiently in the work to take responsibility for the content, and that all those who qualify are listed.

\section{Details of ethics approval}

Not applicable.

\section{Funding}

Central Manchester University Hospitals NHS Foundation Trust provided funding for this study. Dr Jenny Myers is supported by a NIHR Clinician Scientist Fellowship (NIHR-CS-011-020). 


\section{References}

1. Knight M KS, Brocklehurst P, Neilson J, Shakespeare J, Kurinczuk JJ Saving Lives, Improving Mothers' Care: Lessons learned to inform future maternity care from the UK and Ireland Confidential Enquiries into Maternal Deaths and Morbidity 2009-12. Oxford 2014. 2. Gardosi J, Madurasinghe V, Williams M, Malik A, Francis A. Maternal and fetal risk factors for stillbirth: population based study. BMJ. 2013;346:f108

3. Chappell LC, Enye S, Seed P, Briley AL, Poston L, Shennan AH. Adverse perinatal outcomes and risk factors for preeclampsia in women with chronic hypertension: a prospective study. Hypertension. 2008;51(4):1002-9.

4. Tranquilli AL, Dekker G, Magee L, Roberts J, Sibai BM, Steyn W, et al. The classification, diagnosis and management of the hypertensive disorders of pregnancy: A revised statement from the ISSHP. Pregnancy Hypertens. 2014;4(2):97-104.

5. Chappell LC, Duckworth S, Seed PT, Griffin M, Myers J, Mackillop L, et al. Diagnostic accuracy of placental growth factor in women with suspected preeclampsia: a prospective multicenter study. Circulation. 2013;128(19):2121-31.

6. Duckitt K, Harrington D. Risk factors for pre-eclampsia at antenatal booking: systematic review of controlled studies. BMJ. 2005;330(7491):565.

7. Maynard SE, Min JY, Merchan J, Lim KH, Li J, Mondal S, et al. Excess placental soluble fms-like tyrosine kinase 1 (sFlt1) may contribute to endothelial dysfunction, hypertension, and proteinuria in preeclampsia. J Clin Invest. 2003;111(5):649-58.

8. Rajakumar A, Michael HM, Rajakumar PA, Shibata E, Hubel CA, Karumanchi SA, et al. Extra-placental expression of vascular endothelial growth factor receptor-1, (FIt-1) and soluble Flt-1 (sFlt-1), by peripheral blood mononuclear cells (PBMCs) in normotensive and preeclamptic pregnant women. Placenta. 2005;26(7):563-73.

9. Blankley RT, Robinson NJ, Aplin JD, Crocker IP, Gaskell SJ, Whetton AD, et al. A gelfree quantitative proteomics analysis of factors released from hypoxic-conditioned placentae. Reprod Sci. 2010;17(3):247-57.

10. Benton SJ, McCowan LM, Heazell AE, Grynspan D, Hutcheon JA, Senger C, et al. Placental growth factor as a marker of fetal growth restriction caused by placental dysfunction. Placenta. 2016;42:1-8.

11. Zeisler H, Llurba E, Chantraine F, Vatish M, Staff AC, Sennstrom M, et al. Predictive Value of the sFIt-1:PIGF Ratio in Women with Suspected Preeclampsia. N Engl J Med. 2016;374(1):13-22.

12. Chappell LC, Duckworth S, Griffin M, Tarft H, Seed P, Redman CW, et al. OS100. Plasma placental growth factor (PLGF) measurement in women presenting with suspected pre-eclampsia: the pelican study. Pregnancy Hypertens. 2012;2(3):233-4.

13. Griffin M, Seed PT, Duckworth S, North R, Myers J, Mackillop L, et al. Prediction of delivering a small for gestational age infant and adverse perinatal outcome in women with suspected pre-eclampsia. Ultrasound Obstet Gynecol. 2017.

14. The National Institute for Health and Care Excellence (NICE) Diagnostics Assessment Panel. PIGF-based testing to help diagnose suspected pre-eclampsia (Triage PIGF test, Elecsys immunoassay sFIt-1/PIGF ratio, DELFIA Xpress PIGF 1-2-3 test, and BRAHMS sFIt-1 Kryptor/BRAHMS PIGF plus Kryptor PE ratio). Available at:

https://www.nice.org.uk/guidance/dg23. 2016. [Accessed April 2017] 
15. The National Institute for Health and Care Excellence (NICE). Hypertension in pregnancy: diagnosis and management. NICE Guidelines (CG107). Available at: https://www.nice.org.uk/guidance/cg107. 2011. [Accessed April 2017]

16. RCOG. The Investigation and Management of the Small-for-Gestational-Age Fetus. Green-top Guideline No.31. 2014.

17. Pregnancy ATFoHi. Hypertension in pregnancy. Obstet Gynecol. 2013;112.

18. Gardosi J, Chang A, Kalyan B, Sahota D, Symonds EM. Customised antenatal growth charts. Lancet. 1992;339(8788):283-7.

19. Saffer C, Olson G, Boggess KA, Beyerlein R, Eubank C, Sibai BM, et al. Determination of placental growth factor (PIGF) levels in healthy pregnant women without signs or symptoms of preeclampsia. Pregnancy Hypertens. 2013;3(2):124-32.

20. Drewlo S, Levytska K, Sobel M, Baczyk D, Lye SJ, Kingdom JC. Heparin promotes soluble VEGF receptor expression in human placental villi to impair endothelial VEGF signaling. J Thromb Haemost. 2011;9(12):2486-97.

21. Rajakumar A, Cerdeira AS, Rana S, Zsengeller Z, Edmunds L, Jeyabalan A, et al. Transcriptionally active syncytial aggregates in the maternal circulation may contribute to circulating soluble fms-like tyrosine kinase 1 in preeclampsia. Hypertension. 2012;59(2):25664.

22. Korzeniewski SJ, Romero R, Chaiworapongsa T, Chaemsaithong P, Kim CJ, Kim YM, et al. Maternal plasma angiogenic index-1 (placental growth factor/soluble vascular endothelial growth factor receptor-1) is a biomarker for the burden of placental lesions consistent with uteroplacental underperfusion: a longitudinal case-cohort study. Am J Obstet Gynecol. 2016;214(5):629 e1-e17. 


\section{Figure Legends}

Figure 1: The relationship between maternal PIGF concentration $(\mathrm{pg} / \mathrm{ml})$ and test-birth interval (days), using the PIGF result nearest to delivery.

Figure 2: Effect of women's final PIGF results on clinical management ( $n=260) . \%$ refers to the proportion of women within each PIGF category. Maternal surveillance refers to the frequency of clinic visits to monitor maternal condition; maternal management refers to maternal admission status; scan surveillance refers to the frequency of clinic visits to monitor fetal wellbeing; delivery describes the impact of the PIGF result on timing of delivery.

Supplementary Figure 1. Flowchart for clinical management based on adjuvant PIGF testing

\section{Supplementary figure 2: Kaplan-Meier curves for the cumulative incidence of deliveries} throughout gestation in women with low $(<12 \mathrm{pg} / \mathrm{ml}) /$ intermediate $(12-100 \mathrm{pg} / \mathrm{ml}) / \mathrm{normal}$ $(>100 \mathrm{pg} / \mathrm{ml})$ PIGF concentration from 24 weeks; $(\mathbf{p}<0.0001)$. The test-birth interval was calculated as the number of days between the final PIGF test and birth. We observed a much shorter median test-birth interval in women with a low PIGF $<12 \mathrm{pg} / \mathrm{ml}$ (13 [0-54 (range)] days; $\mathrm{n}=61$ ) and those with an intermediate PIGF $13-100 \mathrm{pg} / \mathrm{ml}$ (12 [1-104] days; $\mathrm{n}=75)$, compared to those with a normal PIGF $>100 \mathrm{pg} / \mathrm{ml}(34.5[2-111]$ days; $\mathrm{n}=124) ; \mathrm{p}<0.0001$. 
Figure 1: The relationship between maternal PIGF concentration $(\mathrm{pg} / \mathrm{ml})$ and test-birth interval (days), using the PIGF result nearest to delivery.

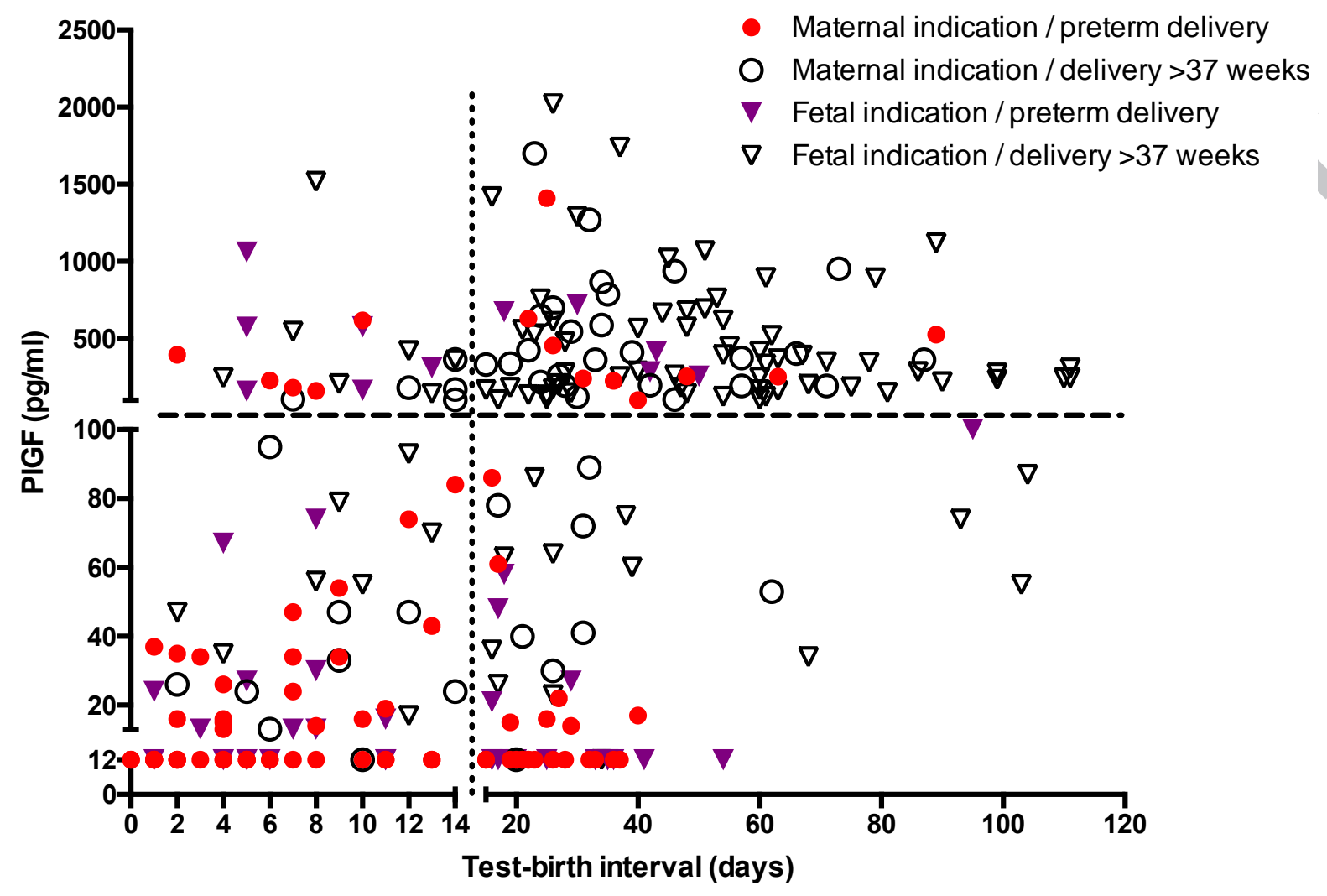


Figure 2: Effect of women's final PIGF results on clinical management $(n=260) . \%$ refers to the proportion of women within each PIGF category. Maternal surveillance refers to the frequency of clinic visits to monitor maternal condition; maternal management refers to maternal admission status; scan surveillance refers to the frequency of clinic visits to monitor fetal wellbeing; delivery describes the impact of the PIGF result on timing of delivery.

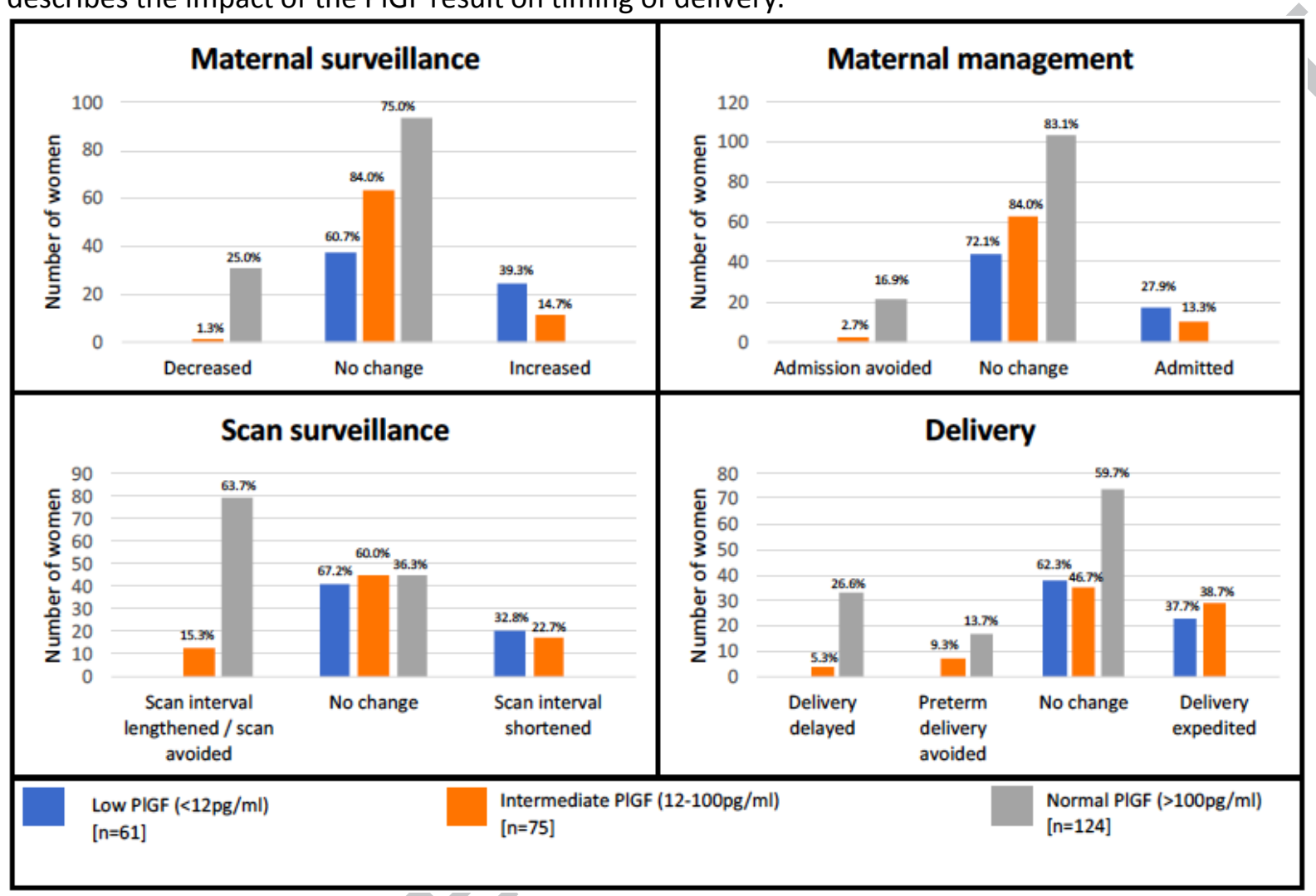


Table 1: Clinical characteristics and demographics of the cohort

\begin{tabular}{|c|c|c|c|c|}
\hline & $\begin{array}{c}\text { No PE/SGA* } \\
(n=71)\end{array}$ & $\begin{array}{c}\text { PE } \\
(n=78)\end{array}$ & $\begin{array}{c}\text { SGA } \\
(n=111)\end{array}$ & $\begin{array}{c}\text { Total } \\
(n=260)\end{array}$ \\
\hline \multicolumn{5}{|l|}{$\begin{array}{l}\text { Indication for } \\
\text { test }\end{array}$} \\
\hline $\begin{array}{r}\text { Maternal } \\
\mathrm{N}(\%)\end{array}$ & $29(40.8 \%)$ & $34(43.6 \%)$ & $12(10.8 \%)$ & $75(28.8 \%)$ \\
\hline $\begin{array}{r}\text { Fetal } \\
\mathrm{N}(\%) \\
\end{array}$ & 37 (52.1\%) & $7(9.0 \%)$ & $88(79.3 \%)$ & $132(50.8 \%)$ \\
\hline $\begin{array}{l}\text { Both } \\
\mathrm{N}(\%)\end{array}$ & $5(7.0 \%)$ & $37(47.4 \%)$ & 11 (9.9\%) & $53(20.4 \%)$ \\
\hline Diabetes, N (\%) & $12(16.9 \%)$ & $12(15.4 \%)$ & $4(3.6 \%)$ & $28(10.8 \%)$ \\
\hline $\begin{array}{l}\text { Pre-existing } \\
\text { Hypertension } \\
\mathrm{N}(\%)\end{array}$ & $24(33.8 \%)$ & 43 (55.1\%) & $15(13.5 \%)$ & $82(31.5 \%)$ \\
\hline $\begin{array}{l}\text { Early pregnancy } \\
\text { proteinuria } \\
\mathrm{N}(\%)\end{array}$ & $16(22.5 \%)$ & 14 (17.9\%) & $4(3.6 \%)$ & $34(13.1)$ \\
\hline \multicolumn{5}{|l|}{ Ethnicity } \\
\hline White, N (\%) & $33(46.5 \%)$ & 31 (39.7\%) & $57(51.4 \%)$ & $121(46.5 \%)$ \\
\hline Black, N (\%) & $6(8.5 \%)$ & $27(34.6 \%)$ & $21(18.9 \%)$ & $54(20.8 \%)$ \\
\hline Asian, N (\%)) & $28(39.4 \%)$ & $18(23.1 \%)$ & $24(21.6 \%)$ & $70(26.9 \%)$ \\
\hline Other, N (\%) & $5(7.0 \%)$ & $2(2.6 \%)$ & $8(7.2 \%)$ & $15(5.8 \%)$ \\
\hline $\begin{array}{l}\mathrm{BMI}\left(\mathrm{kg} / \mathrm{cm}^{2} \text { ) }\right. \\
\text { Median (range) }\end{array}$ & $\begin{array}{c}26.13 \\
(18.79-44.08) \\
\end{array}$ & $\begin{array}{c}30.43 \\
(20.20-50.07) \\
\end{array}$ & $\begin{array}{c}24.21 \\
(17.21-41.28) \\
\end{array}$ & \\
\hline $\begin{array}{l}\text { Gestation } \\
\text { (weeks+days) at } \\
\text { testing } \\
\text { Median (range) }\end{array}$ & $\begin{array}{c}33+4(23+0 \\
40+0)\end{array}$ & $\begin{array}{c}31+6(23+1- \\
41+2)\end{array}$ & $\begin{array}{c}32+4(23+1- \\
38+3)\end{array}$ & \\
\hline $\begin{array}{l}\text { Test-birth } \\
\text { interval (days) } \\
\text { Median (range) } \\
\end{array}$ & $28(1-111)$ & $13(0-78)$ & $25.5(1-104)$ & \\
\hline $\begin{array}{l}\text { Gestation at } \\
\text { delivery } \\
\text { (weeks+days) } \\
\text { Median (range) }\end{array}$ & $\begin{array}{c}37+4(31+6- \\
42+2)\end{array}$ & $\begin{array}{c}34+6(26+0- \\
41+4)\end{array}$ & $\begin{array}{c}37+1(26+3- \\
42+0)\end{array}$ & \\
\hline $\begin{array}{l}\text { Number <34 } \\
\text { weeks ( } \mathrm{n})\end{array}$ & $4(5.6 \%)$ & $32(41.0 \%)$ & $22(19.8 \%)$ & $58(22.3 \%)$ \\
\hline $\begin{array}{l}\text { Number }<10^{\text {th }} \\
\text { centile, } \mathrm{N}(\%)\end{array}$ & $0(0.0 \%)$ & $50(64.1 \%)$ & $111(100.0 \%)$ & 161 (61.9\%) \\
\hline FDIU, N (\%) & 0 & 0 & $3(2.7 \%)$ & $3(1.2 \%)$ \\
\hline
\end{tabular}

PE pre-eclampsia (clinical diagnosis), SGA small for gestational age $\left(<10^{\text {th }}\right.$ centile), FDIU fetal death in utero. ${ }^{*}$ includes women with maternal or fetal complications (including preterm birth) if the birthweight was $>10^{\text {th }}$ centile and there was no clinical diagnosis of PE.

Data is mean(SD), $\mathrm{n}(\%)$. 
Table 2: Summary measures of diagnostic accuracy for PIGF against clinical diagnoses using different concentration / centile cut-offs for a complicated pregnancy.

\begin{tabular}{|c|c|c|c|c|c|c|}
\hline & Sensitivity & Test +ve & Specificity & Test -ve & ROC & $95 \% \mathrm{Cl}$ \\
\hline \multicolumn{7}{|c|}{ Complicated pregnancy; test-birth interval <14 days $(85 / 93)$} \\
\hline PIGF $<100 \mathrm{pg} / \mathrm{ml}$ & $80.0 \%$ & 74 & $25.0 \%$ & 19 & 0.51 & $0.43-0.59$ \\
\hline PIGF $<50 \mathrm{pg} / \mathrm{ml}$ & $70.6 \%$ & 64 & $50.0 \%$ & 29 & 0.54 & $0.47-0.61$ \\
\hline PIGF $<5^{\text {th }}$ centile $\neq$ & $63.5 \%$ & 56 & $75.0 \%$ & 37 & 0.56 & $0.50-0.63$ \\
\hline PIGF $<3$ rd centile & $61.2 \%$ & 53 & $87.5 \%$ & 40 & 0.58 & $0.52-0.64$ \\
\hline \multicolumn{7}{|c|}{ Complicated pregnancy; any test-birth interval $(206 / 260)$} \\
\hline $\mathrm{PIGF}<100 \mathrm{pg} / \mathrm{ml}$ & $61.2 \%$ & 136 & $81.5 \%$ & 124 & 0.64 & $0.59-0.69$ \\
\hline $\mathrm{PIGF}<50 \mathrm{pg} / \mathrm{ml}$ & $51.0 \%$ & 109 & $92.6 \%$ & 151 & 0.65 & $0.61-0.69$ \\
\hline PIGF $<5^{\text {th }}$ centile & $52.9 \%$ & 114 & $90.7 \%$ & 146 & 0.65 & $0.60-0.69$ \\
\hline \multirow[t]{2}{*}{ PIGF $<3$ rd centile } & $50.5 \%$ & 107 & $94.4 \%$ & 153 & 0.65 & $0.61-0.69$ \\
\hline & Sensitivity & Test + ve & Specificity & Test -ve & ROC & $95 \% \mathrm{Cl}$ \\
\hline \multicolumn{7}{|c|}{$\begin{array}{l}\text { Preterm delivery; gestation at testing }<37 \text { weeks; test test-birth interval }<14 \text { days } \\
(69 / 88)\end{array}$} \\
\hline $\mathrm{PIGF}<100 \mathrm{pg} / \mathrm{ml}$ & $84.1 \%$ & 72 & $26.3 \%$ & 16 & 0.56 & $0.43-0.69$ \\
\hline $\mathrm{PIGF}<50 \mathrm{pg} / \mathrm{ml}$ & $78.3 \%$ & 62 & $57.9 \%$ & 26 & 0.65 & $0.54-0.75$ \\
\hline PIGF $<5^{\text {th }}$ centile & $75.4 \%$ & 56 & $78.9 \%$ & 32 & 0.70 & $0.60-0.79$ \\
\hline PIGF $<3$ rd centile & $72.5 \%$ & 53 & $84.2 \%$ & 35 & 0.70 & $0.61-0.79$ \\
\hline \multicolumn{7}{|c|}{ Preterm delivery; gestation at testing <37 weeks; any test-birth interval $(123 / 255)$} \\
\hline $\mathrm{PIGF}<100 \mathrm{pg} / \mathrm{ml}$ & $79.7 \%$ & 134 & $72.7 \%$ & 121 & 0.76 & $0.71-0.81$ \\
\hline PIGF <50pg/ml & $72.4 \%$ & 107 & $86.4 \%$ & 148 & 0.80 & $0.75-0.85$ \\
\hline PIGF $<5^{\text {th }}$ centile & $73.2 \%$ & 114 & $81.8 \%$ & 141 & 0.78 & $0.72-0.83$ \\
\hline PIGF $<3$ rd centile & $70.7 \%$ & 107 & $84.8 \%$ & 148 & 0.78 & $0.73-0.84$ \\
\hline
\end{tabular}

Preterm delivery was defined as delivery before 37 weeks' gestation; $n=70 / 94$ (median gestation at delivery: 245 (182-258) days).

Complicated pregnancy was defined by preterm birth/ SGA $<10^{\text {th }}$ centile / PE and did not include women with maternal disease only (no features of placental disease); $n=85 / 99$.

$\ddagger \mathrm{PIGF}$ centile (adjusted for gestation) calculated using data from Saffer et al.(19) 
Supplementary Table 1: Test-birth interval depending on PIGF indication and pregnancy outcome

\begin{tabular}{|l|l|c|c|c|}
\hline \multicolumn{2}{|c|}{} & \multicolumn{3}{|c|}{ Test-birth interval (days) } \\
\cline { 2 - 5 } & Median & Range & Frequency \\
\hline \multirow{4}{*}{$\begin{array}{l}\text { Indication for } \\
\text { PIGF }\end{array}$} & $14^{* * *}$ & $0-89$ & 75 \\
\cline { 2 - 5 } & $\begin{array}{l}\text { Fetal (no features of } \\
\text { maternal disease) }\end{array}$ & 27.5 & $1-111$ & 132 \\
\cline { 2 - 5 } & $\begin{array}{l}\text { Mixed (maternal \& } \\
\text { fetal indication) }\end{array}$ & $15^{* * *}$ & $1-57$ & 53 \\
\hline \multirow{4}{*}{$\begin{array}{l}\text { Pregnancy } \\
\text { Outcome }\end{array}$} & Uncomplicated $¥$ & 31 & $4-111$ & 50 \\
\cline { 2 - 5 } & PE & $13^{\text {1919 }}$ & $0-78$ & 78 \\
\cline { 2 - 5 } & SGA & $26^{\text {II }}$ & $1-104$ & 105 \\
\cline { 2 - 5 } & $\begin{array}{l}\text { Other maternal } \\
\text { Other fetal (including } \\
\text { preterm) }\end{array}$ & 19 & $6-48$ & 11 \\
\cline { 2 - 5 } & $\begin{array}{l}\text { Intrauterine fetal } \\
\text { death }\end{array}$ & 23 & $11-54$ & 3 \\
\hline
\end{tabular}

¥Live term delivery with no maternal / fetal complications.

$* * * P=0.001$ median test to delivery interval compared to fetal indication alone.

ๆ $\mathrm{P}<0.05$ \& ๆๆ $\mathrm{P}<0.0001$ compared to uncomplicated pregnancy outcome. 
Supplementary table 2: Details of the pregnancies with false positive $\&$ false negative PIGF results against a clinical diagnosis of PE or a medically-indicated preterm birth, using cut-offs of $<12 \mathrm{pg} / \mathrm{ml}$ and $\geq 100 \mathrm{pg} / \mathrm{ml}$.

\begin{tabular}{|c|c|c|c|c|c|c|c|}
\hline \multicolumn{8}{|c|}{ Women with a low PIGF without a clinical diagnosis PE } \\
\hline $\begin{array}{c}\text { Test- } \\
\text { birth } \\
\text { interval } \\
\text { (days) }\end{array}$ & $\begin{array}{c}\text { Gestation at } \\
\text { birth } \\
\text { (weeks + days) }\end{array}$ & $\begin{array}{c}\text { BW } \\
\text { (grams) }\end{array}$ & $\begin{array}{l}\text { BW } \\
\text { centile }\end{array}$ & $\begin{array}{c}\text { PIGF } \\
(\mathrm{pg} / \mathrm{ml})\end{array}$ & $\begin{array}{l}\text { PIFG } \\
\text { centile } \ddagger\end{array}$ & $\begin{array}{c}\text { Gestation at } \\
\text { test } \\
\text { (weeks + days) }\end{array}$ & Diagnosis comments \\
\hline 19 & $36+6$ & 3080 & 73.0 & $<12$ & 0.1 & $34+1$ & $\begin{array}{l}\text { GDM, proteinuria, } \\
\text { transient HTN }\end{array}$ \\
\hline 41 & $31+6$ & 1540 & 15.0 & $<12$ & 0.0 & $26+0$ & $\begin{array}{l}\text { Spontaneous preterm } \\
\text { labour, renal disease }\end{array}$ \\
\hline \multicolumn{8}{|c|}{ Women with a normal PIGF (within 2 weeks of birth) with a clinical diagnosis of PE } \\
\hline 12 & $37+0$ & 2610 & 10.2 & 183 & 37.0 & $35+2$ & HTN, new proteinuria \\
\hline 7 & $35+6$ & 2320 & 24.6 & 183 & 33.6 & $34+6$ & $\begin{array}{l}\text { HTN, pulmonary HTN, } \\
\text { worsening proteinuria }\end{array}$ \\
\hline 14 & $37+2$ & 2350 & 3.5 & 172 & 34.9 & $35+2$ & $\begin{array}{c}\text { T1 DM, FGR, pre-existing } \\
\text { proteinuria }\end{array}$ \\
\hline \multicolumn{8}{|c|}{ Women with a normal PIGF (within 2 weeks of birth) with an indication for preterm birth } \\
\hline 10 & $35+6$ & 3040 & 82.3 & 619 & 72.4 & $34+3$ & $\begin{array}{c}\begin{array}{c}\text { Induced for other } \\
\text { maternal disease }\end{array} \\
\end{array}$ \\
\hline 10 & $34+2$ & 2883 & 89.7 & 577 & 63.0 & $32+6$ & Induced for previous IUD \\
\hline 13 & $36+6$ & 2750 & 21.4 & 312 & 53.0 & $35+0$ & Induced for suspected SGA \\
\hline 5 & $36+1$ & 1998 & 0.4 & 574 & 75.1 & $35+3$ & Induced for FGR \\
\hline 6 & $34+6$ & 2334 & 18.6 & 229 & 34.1 & $34+0$ & $\begin{array}{c}\text { Induced for maternal } \\
\text { disease (renal HTN) }\end{array}$ \\
\hline 5 & $32+4$ & 1447 & 1.6 & 159 & 10.4 & $31+6$ & $\begin{array}{c}\text { Delivered for CTG } \\
\text { abnormality }\end{array}$ \\
\hline 8 & $33+6$ & 2649 & 67.8 & 161 & 15.1 & $32+5$ & $\begin{array}{c}\text { Delivered for maternal } \\
\text { cardiac disease }\end{array}$ \\
\hline 2 & & 2061 & 29.9 & 395 & 49.1 & $33+1$ & $\begin{array}{c}\text { Spontaneous preterm } \\
\text { labour }\end{array}$ \\
\hline 5 & & 2800 & 44.3 & 1060 & 89.9 & $35+6$ & Induced for previous IUD \\
\hline 10 & $32+1$ & 1497 & 3.7 & 165 & 7.0 & $30+5$ & Delivered due to abruption \\
\hline
\end{tabular}

BW birthweight, HTN hypertension, GDM gestational diabetes, T1 DM type 1 diabetes mellitus. $\ddagger P I G F$ centile (adjusted for gestation) calculated using data from Saffer et al.(19) 
Supplementary table 3: Summary measures of diagnostic accuracy for PIGF using low $(<12 \mathrm{pg} / \mathrm{ml})$ or intermediate $\left(<100 \mathrm{pg} / \mathrm{ml}\right.$ ) cut-offs against a clinical diagnosis of PE, SGA (BW centile $<10^{\text {th }}$ in the absence of features of maternal disease), preterm delivery ( $<37$ weeks), and maternal complications (in the absence of SGA / PE).

\begin{tabular}{|c|c|c|c|c|c|c|}
\hline & Sensitivity & Test +ve & Specificity & Test -ve & ROC & $95 \% \mathrm{Cl}$ \\
\hline \multicolumn{7}{|c|}{ PE; test-birth interval<14 days $(41 / 50)$} \\
\hline PIGF $<12 \mathrm{pg} / \mathrm{ml}$ & $51.2 \%$ & 21 & $100.0 \%$ & 29 & 0.66 & $0.57-0.74$ \\
\hline $\mathrm{PIGF}<100 \mathrm{pg} / \mathrm{ml}$ & $95.1 \%$ & 45 & $33.3 \%$ & 5 & 0.73 & $0.49-0.98$ \\
\hline \multicolumn{7}{|c|}{ PE; any test-birth interval (78/128) } \\
\hline PIGF $<12 \mathrm{pg} / \mathrm{ml}$ & $50.0 \%$ & 39 & $100.0 \%$ & 89 & 0.78 & $0.73-0.83$ \\
\hline PIGF $<100 \mathrm{pg} / \mathrm{ml}$ & $85.9 \%$ & 75 & $84.0 \%$ & 53 & 0.84 & $0.78-0.91$ \\
\hline \multicolumn{7}{|c|}{ SGA; test-birth interval<14 days (35/44) } \\
\hline PIGF $<12 \mathrm{pg} / \mathrm{ml}$ & $31.4 \%$ & 11 & $100.0 \%$ & 33 & 0.64 & $0.56-0.71$ \\
\hline $\mathrm{PIGF}<100 \mathrm{pg} / \mathrm{ml}$ & $77.1 \%$ & 33 & $33.3 \%$ & 11 & 0.55 & $0.39-0.70$ \\
\hline \multicolumn{7}{|c|}{ SGA; any test-birth interval (111/161) } \\
\hline PIGF $<12 \mathrm{pg} / \mathrm{ml}$ & $18.0 \%$ & 20 & $100.0 \%$ & 141 & 0.68 & $0.64-0.72$ \\
\hline PIGF $<100 \mathrm{pg} / \mathrm{ml}$ & $49.5 \%$ & 63 & $84.0 \%$ & 98 & 0.65 & $0.59-0.72$ \\
\hline \multicolumn{7}{|c|}{ Preterm; gestation at testing $<37$ weeks; test-birth interval< 14 days $(69 / 88)$} \\
\hline $\mathrm{PIGF}<12 \mathrm{pg} / \mathrm{ml}$ & $44.9 \%$ & 32 & $94.7 \%$ & 56 & 0.65 & $0.58-0.71$ \\
\hline $\mathrm{PIGF}<100 \mathrm{pg} / \mathrm{ml}$ & $84.1 \%$ & 72 & $26.3 \%$ & 16 & 0.56 & $0.43-0.69$ \\
\hline \multicolumn{7}{|c|}{ Preterm; gestation at testing $<37$ weeks; any test-birth interval $(123 / 255)$} \\
\hline $\mathrm{Plgf}<12 \mathrm{pg} / \mathrm{ml}$ & $47.2 \%$ & 61 & $97.7 \%$ & 194 & 0.81 & $0.76-0.85$ \\
\hline $\mathrm{PIGF}<100 \mathrm{pg} / \mathrm{ml}$ & $79.7 \%$ & 134 & $72.7 \%$ & 121 & 0.76 & $0.71-0.81$ \\
\hline
\end{tabular}

Diagnostic accuracy for each of the above outcomes was compared to women without complications.

SGA small for gestational age, PE pre-eclampsia. 


\section{Supplementary Figure 1. Flowchart for clinical management based on adjuvant PIGF testing}

Criteria for testing: Worsening hypertension (in women with $\mathrm{CHT}$ ), new proteinuria, maternal symptoms, suspected FGR (EFWC $<10^{\text {th }}$ centile, Oligohydramnios, abnormal Dopplers, reduced growth trajectory) NO IMMEDIATE INDICATION FOR DELIVERY

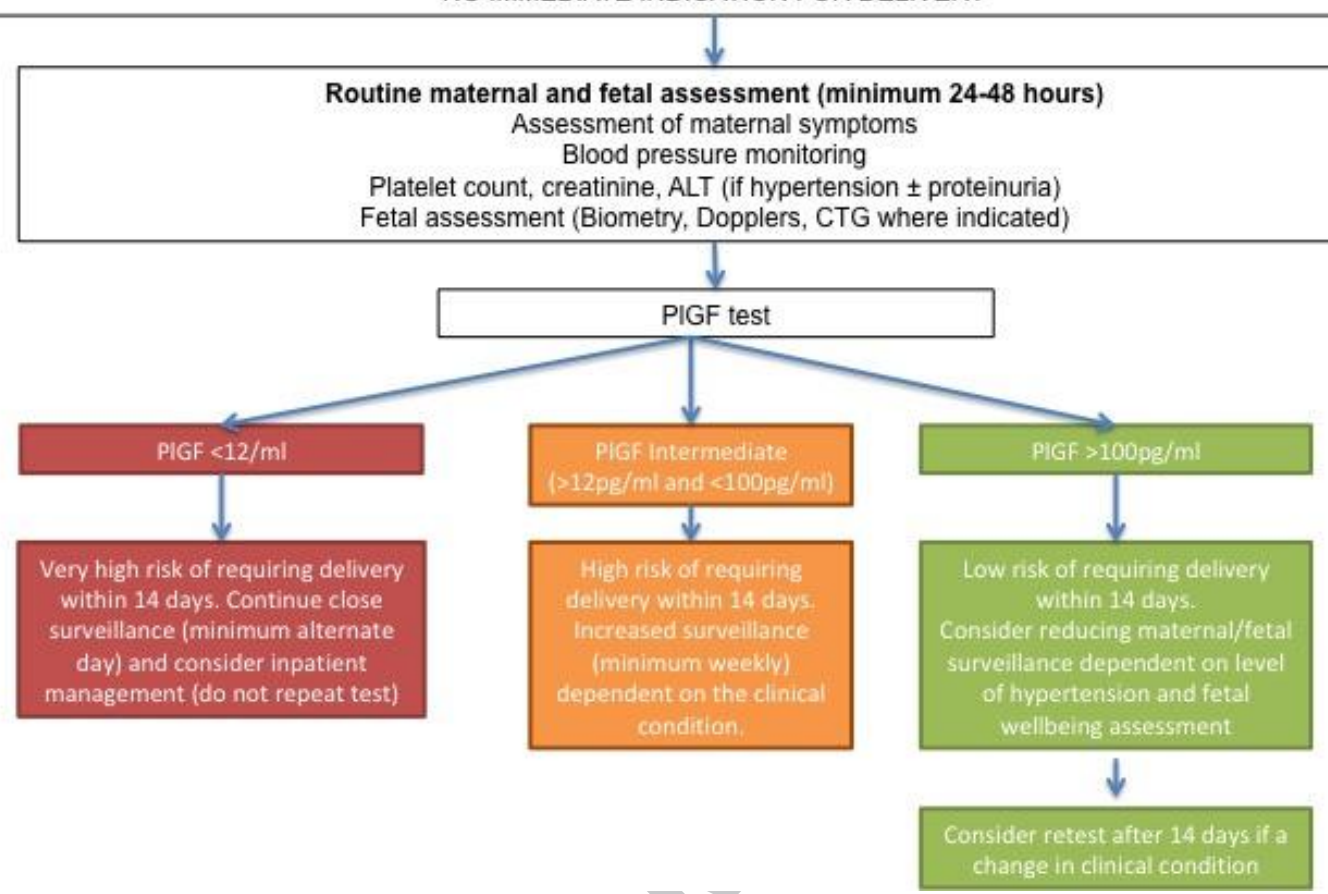


Supplementary figure 2: Kaplan-Meier curves for the cumulative incidence of deliveries throughout gestation in women with low $(<12 \mathrm{pg} / \mathrm{ml}) /$ intermediate $(12-100 \mathrm{pg} / \mathrm{ml}) /$ normal $(>100 \mathrm{pg} / \mathrm{ml})$ PIGF concentration from 24 weeks; $(p<0.0001)$.

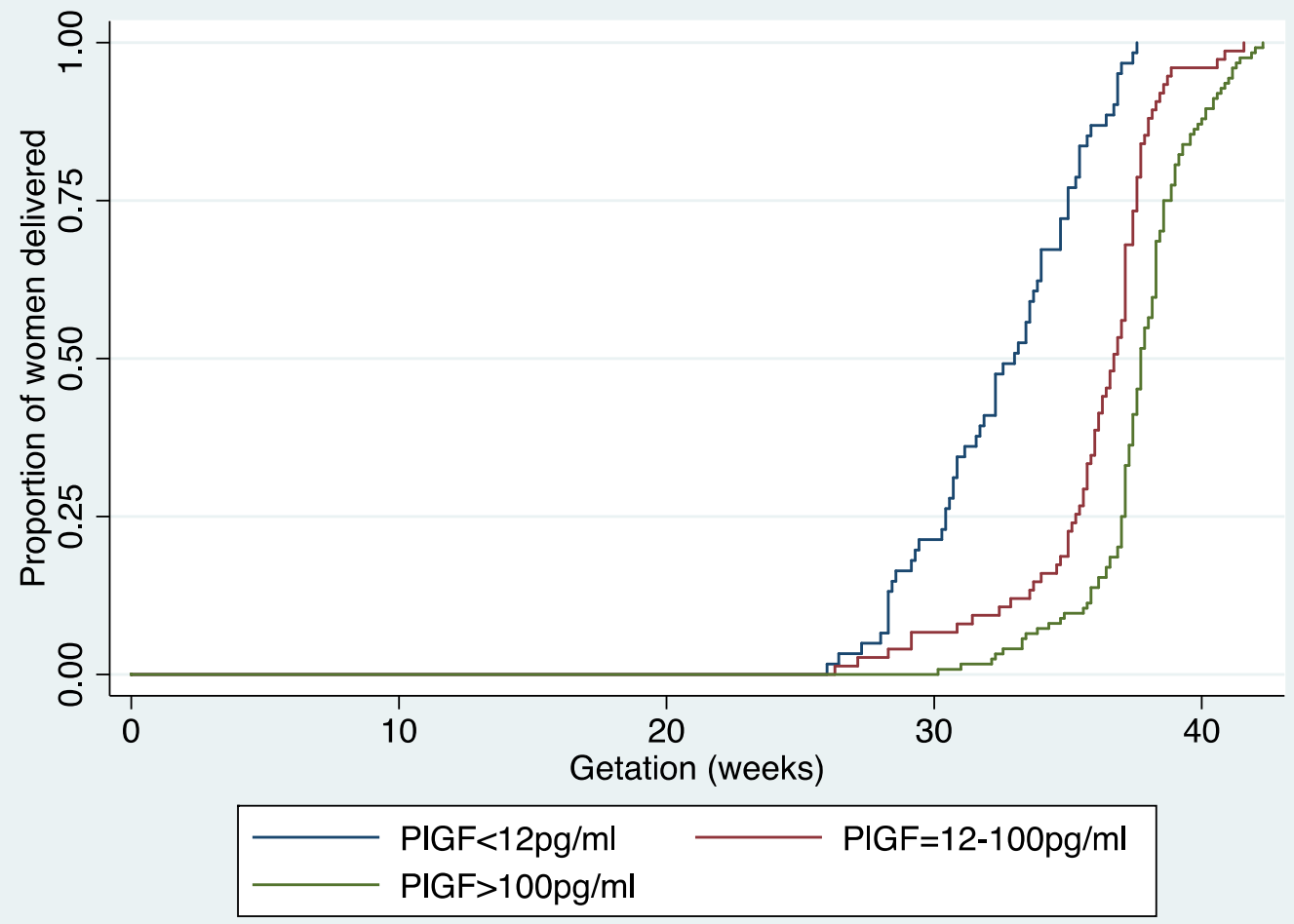

The test-birth interval was calculated as the number of days between the final PIGF test and birth. We observed a much shorter median test-birth interval in women with a low PIGF $<12 \mathrm{pg} / \mathrm{ml}$ (13 [054 (range)] days; $n=61$ ) and those with an intermediate PIGF 13-100pg/ml (12 [1-104] days; $n=75)$, compared to those with a normal PIGF $>100 \mathrm{pg} / \mathrm{ml}$ (34.5 [2-111] days; $n=124) ; p<0.0001$. 


\section{Highlights}

- We report the real-time impact of Placental growth factor (PIGF) testing in a cohort of high risk pregnancies presenting to a tertiary centre

- In high risk pregnancies, where the diagnosis of pre-eclampsia and/or fetal growth restriction can often be challenging, we confirm that placental growth factor is a useful adjunct to standard clinical care

- In the majority of cases the PIGF result had an impact on scan surveillance, maternal surveillance and obstetric intervention

- A very low PIGF $(<12 \mathrm{pg} / \mathrm{ml})$ was universally associated with a poor pregnancy outcome in this cohort

- Half of the pregnancies with a very low PIGF continued beyond 14 days after testing, confirming that PIGF should not be used to trigger delivery 